\title{
PENGARUH TRAIT KEPRIBADIAN TERHADAP AKTIVITAS FISIK
}

\author{
Welan Mauli Angguna
}

Fakultas Psikologi Universitas Putra Indonesia 'YPTK' Indonesia Padang, email: welanmauli@gmail.com

\section{ABSTRACT: THE EFFECTS OF PERSONALITY TRAITS ON PHYSICAL ACTIVITY}

Indonesia was considered as a country who has low physical activity. Hence, it was necessary to promote physical activity in order preventing degenerative disease and death in young adults. Personality traits were good predictors of physical activity. The purpose of this study was to examine the effects of personality traits on physical activity. This is a survey analytical study cross-sectional design on 33 samples aged 18-26 years old. The study found that personalities traits influenced physical activity with contribution $32 \%(p \leq 0,05)$, especially of extraversion, agreeableness, and openness. There was significant difference of physical activity based on gender and exercise routine, this should be a consideration for further research.

\section{Keywords: Personality Traits, Physical Activity, Gender.}

Indonesia dianggap sebagai negara dengan aktivitas fisik yang cukup rendah, sehingga diperlukan promosi aktivitas fisik untuk pencegahan terhadap penyakit degeneratif dan kematian di usia muda. Trait kepribadian dianggap sebagai faktor psikologis kuat dalam identifikasi aktivitas fisik. Penelitian ini adalah survei analitik dengan rancangan cross-sectional pada 33 sampel usia 18-26 tahun yang rutin dan tidak rutin berolahraga. Hasil penelitian menunjukkan bahwa trait kepribadian berkontribusi sebesar $32 \%$ $(p \leq 0,05)$ terhadap aktivitas fisik, khususnya trait ekstraversi, agreeableness, dan openness. Adanya perbedaan signifikan aktivitas fisik dan trait kepribadian antar gender dan rutinitas berolahraga, hal ini disarankan menjadi pertimbangan untuk penelitian lanjutan.

\section{Kata Kunci: Trait Kepribadian, Aktivitas Fisik, Gender.}

\section{PENDAHULUAN}

Penyakit tidak menular atau penyakit degeneratif akhir-akhir ini menarik perhatian sebagai faktor risiko penyebab kematian di dunia (WHO, 2017). Hal ini sejalan dengan temuan Badan Penelitian dan Pengembangan Kementrian Kesehatan Republik Indonesia (2014) bahwa tujuh dari 10 penyebab kematian utama di Indonesia adalah penyakit degeneratif yaitu stroke, jantung iskemik dan diabetes (cnnindonesia, 2017; Kemenkes RI, 2017). Menurut WHO (2017), kekurangan aktivitas fisik merupakan faktor penting penyebab penyakit tidak menular/penyakit degeneratif sehingga dianggap sebagai salah satu faktor risiko yang membawa kematian di dunia, karena sesungguhnya penyakit ini bisa dicegah dengan menjalani gaya hidup sehat, seperti mengurangi rokok, melakukan aktivitas fisik, dan tidak mengonsumsi alkohol (Kemenkes, 2017).

Penyakit degeneratif biasanya terjadi pada kelompok umur setelah dewasa madya, namun gangguan fisiologis penyakit ini mulai berkembang lebih awal dan berakumulasi sepanjang fase kehidupan (Weintraub dalam Israel, Moffitt, Belsky, Hancox, Poulton, Roberts, Thomson, \& Caspi, 2014), artinya penyakit ini mulai menyerang kelompok umur yang lebih 


\section{PENGARUH TRAIT KEPRIBADIAN TERHADAP AKTIVITAS FISIK}

muda. Seiring dengan berkembangnya teknologi dan berbagai faktor risiko semakin berkembang pula jumlah anak muda yang menjalani gaya hidup tidak sehat dan kekurangan aktivitas fisik sehingga semakin rentan terhadap penyakit degeneratif (Macovei, Tufan, \& Vulpe, 2014). Pada tahun 2008 diperkirakan 17,3 juta kematian disebabkan penyakit degeneratif dan lebih 3 juta kematian tersebut terjadi pada usia di bawah 60 tahun (antaranews, 2017).

Jika ditinjau dari faktor risiko penyebab penyakit degeneratif, tidak heran jika penyakit ini menjadi penyebab utama kematian di Indonesia, khususnya terkait kekurangan aktivitas fisik. Berdasarkan survei yang dilakukan Tim Althoff dari Stanford University diketahui bahwa Indonesia termasuk negara yang minim aktivitas fisik khususnya dalam berjalan kaki, selain itu penduduk Indonesia yang mengalami obesitas berusia di atas 18 tahun juga mengalami peningkatan dari 15,4\% pada tahun 2013 menjadi 20,5\% di tahun 2016 (BBC, 2017).

Aktivitas fisik menurut WHO (2017) adalah pergerakan tubuh oleh kerangka otot yang membutuhkan pengeluaran energi, termasuk aktivitas yang terjadi ketika bekerja, bermain, mengerjakan pekerjaan rumah tangga, dan berekreasi. Aktivitas fisik perlu dibedakan dengan olahraga (exercise), dimana olahraga sebenarnya adalah sub kategori aktivitas fisik yang terencana, terstruktur, berulang, dan bertujuan untuk meningkatkan/ mempertahankan satu atau lebih komponen kesehatan fisik (WHO, 2017). Aktivitas fisik digolongkan atas aktivitas ringan, sedang dan berat, pengelompokan ini berbeda tergantung pada seberapa besar energi yang diketahui dari perubahan pernapasan dan ketahanan dalam melakukan aktivitas tersebut (Nurmalia, dalam Apriana, Julia, \& Huriyati, 2015). Pada orang dewasa (usia 18-64 tahun) perlu melakukan paling sedikit aktivitas fisik moderat selama 150 menit/minggu, dan aktivitas fisik kuat selama 75 menit/minggu demi menjaga kesehatan tubuh (WHO, 2017). Aktivitas fisik dan olahraga selain membuat tubuh menjadi lebih indah juga berasosiasi dengan kesehatan (fisik maupun mental), mengurangi risiko kematian, dan kualitas hidup yang lebih baik (Butkovic, Hlupic, \& Bratko, 2017; Stephan, Sutin, \& Terracciano, 2014; Macovei, Tufan, Vulpe 2014).

Faktor yang membuat seseorang menjadi lebih aktif atau lebih tidak aktif beraktivitas dipengaruhi oleh variabel yang terkait dalam kategori demografis, personal, sosial, dan lingkungan (Rhodes \& Nigg, 2011). Intensi, kemampuan pribadi, keterampilan dalam bertingkahlaku, komitmen dan umpan balik dari lingkungan muncul sebagai faktor penentu yang menetap antar populasi, situasi kondisi, dan modus aktivitas (Dishman, Sallis, \& Orenstein, 1985). Dishman, Sallis, dan Orenstein (1985) meyakinkan bahwa keputusan individu untuk menjadi aktif/ tidak aktif dalam beraktivitas tergantung pada pribadi individu, namun hambatan lingkungan menjadi penting bagi intensi pribadi untuk memunculkan tingkah laku ini.

Welan Mauli Angguna, Fakultas Psikologi Universitas Putra Indonesia 'YPTK', Padang Indonesia, Email:welanmauli@gmail.com 


\section{PENGARUH TRAIT KEPRIBADIAN TERHADAP AKTIVITAS FISIK}

Studi terbaru mengenai promosi kesehatan dan psikologi olahraga memfokuskan pada identifikasi variabel psikologis seperti kepribadian, presentasi diri, dan motivasi yang memengaruhi tingkah laku berolahraga (Asci, Lindwall, Altintas, \& Gursel, 2015). Butkovic, Hlupic, dan Bratko (2017) menjelaskan bahwa ada beberapa alasan yang membuat manusia memutuskan untuk berolahraga atau tidak, dan kepribadian adalah variabel pasti terkait dengan variabel psikologis. Psikologis dapat dipaparkan sebagai sejumlah trait psikologis dan mekanisme yang mengatur individu, relative menetap, dan memngaruhi interaksi dan adaptasi fisik, intrafisik, dan lingkungan sosial sehingga dianggap sebagai variabel psikologis yang dianggap cukup kuat mampu menjelaskan aktivitas fisik (Butkovic, Hlupic, dan Bratko 2017).

Pola hubungan trait kepribadian dengan aktivitas fisik bisa berbeda tergantung karakteristik partisipan dan analisis yang digunakan. Berbagai penelitian menunjukkan bahwa ekstraversi dan conscientiousness yang tinggi disertai dengan neuroticism yang rendah berkaitan dengan tingginya aktivitas fisik (Rhodes \& Smith, 2006; Lochbaoum, Rhodes, \& Stevenson, 2010; Kern, Reynolds, \& Friedman, 2010). Butkovic, Hlupic, \& Bratko (2017) menemukan bahwa terdapat perbedaan biologis/ predisposisi individu untuk melakukan aktivitas fisik, dan kepribadian khususnya ekstraversi dan neuroticism secara signifikan memengaruhi aktivitas fisik. Berbeda dengan
Asci, Lindwall, Altintas, dan Gursel (2015) yang justru menemukan asosiasi signifikan antara trait kepribadian agreeableness dan neuroticism rendah disertai conscientiousness yang tinggi dengan semakin banyak menghabiskan waktu melakukan aktivitas fisik yang berat pada laklaki, namun openness yang rendah justru memengaruhi aktivitas fisik moderat pada perempuan. Menariknya, pada penelitian ini trait ekstraversi tidak berhubungan dengan aktivitas fisik baik pada laki-laki maupun perempuan (Asci, Lindwall, Altintas, \& Gursel 2015).

Temuan yang berbeda-beda ini menunjukkan bahwa trait kepribadian dan aktivitas fisik adalah konstruk yang dinamis, sehingga diperlukan pengukuran objektif pada pengukuran aktivitas fisik ,untuk meningkatkan pemahaman hubungan kepribadian dan aktivitas fisik yang lebih baik dilakukan dengan menggunakan desain prospektif disertai gambaran sampel yang detail (Wilson \& Dishman, 2015; Asci, Lindwall, Altintas, \& Gursel, 2015).

Berbagai temuan menunjukkan bahwa gaya hidup dengan aktivitas fisik aktif adalah penting untuk menjaga kesehatan. Kepribadian dianggap sebagai variabel psikologis penting yang bisa membedakan mengapa individu tertentu lebih aktif dan yang lain tidak. Hubungan ini cenderung berbeda antar jenis kelamin dimana laki-laki cenderung memiliki aktivitas fisik yang lebih tinggi daripada perempuan (Lochbaum, Rhodes, Stevenson, Surles, \& Wang, 2010; Asci, Lindwall, Altintas, \&

Welan Mauli Angguna, Fakultas Psikologi Universitas Putra Indonesia 'YPTK', Padang Indonesia, Email: welanmauli@gmail.com 


\section{PENGARUH TRAIT KEPRIBADIAN TERHADAP AKTIVITAS FISIK}

Gursel 2015; Coen, Rosenberg, \& Davidson, 2018), selain itu perbedaan pola hubungan kepribadian dan aktivitas fisik mungkin juga dipengaruhi oleh karakteristik sampel, seperti ada penelitian yang menggunakan sampel umum dewasa muda dan penelitian lainnya menggunakan sampel dewasa muda yang rutin berolahraga (Asci, Lindwall, Altintas, \& Gursel, 2015).

Aktivitas fisik diketahui sebagai salah satu faktor pencegahan terhadap risiko penyakit degeneratif, namun data di Indonesia menunjukkan bahwa orang-orang di negara ini cenderung memiliki aktivitas fisik rendah, selain itu orang berusia di atas 18 tahun yang mengalami obesitas juga mengalami peningkatan yang cukup tinggi. Oleh sebab itu penting untuk dilakukan studi untuk melihat bagaimana aktivitas fisik orang Indonesia khususnya pada kelompok dewasa muda, karena tanda-tanda patologi penyakit degeneratif mulai berkembang pada usia yang lebih muda. Dalam rangka mencaritahu hal apa saja yang memengaruhi seseorang melakukan aktivitas fisik aktif atau tidak berdasarkan variabel psikologis, maka merujuk pada penelitian sebelumnya, penelitian ini akan menguji apakah trait kepribadian memiliki pengaruh signifikan terhadap aktivitas fisik, dan trait kepribadian apa saja yang memengaruhi aktivitas fisik secara signifikan. Penelitian ini juga akan menguji perbedaan aktivitas fisik dan trait kepribadian antara laki-laki dan perempuan, begitu juga perbedaan aktivitas fisik dan kepribadian antara kelompok dewasa muda yang rutin berolahraga dengan kelompok yang tidak rutin berolahraga.

\section{METODE}

Penelitian ini adalah studi non eksperimental yang ingin melihat pengaruh kepribadian dan presentasi diri dalam olahraga terhadap aktivitas fisik individu. Karakteristik sampel penelitian ini adalah laki-laki atau perempuan dewasa muda yang berusia antara 18 hingga 34 tahun yang secara sukarela menjadi responden penelitian.

Pengumpulan data dilakukan secara accidental sampling, dimana peneliti mendatangi responden di perpustakaan pusat Universitas Indonesia, Pusat Olahraga "GS" Kelapa DuaDepok, Fakultas Psikologi Universitas Indonesia, dan Fakultas Teknik Universitas Negeri Jakarta. Peneliti mendatangi calon responden untuk meminta kesediaan menjadi responden penelitian. Ketika calon responden setuju, peneliti memeberikan penjelasan tujuan pengisian kuesioner, menjelaskan tentang hak dan kewajiban responden lalu mempersilakan calon responden untuk membaca lembar informed concent. Jika calon responden sudah paham dan setuju, calon responden diminta untuk menandatangai lembar informed concent. Setelah itu peneliti memberikan penjelasan tentang tata cara pengisian kuesioner, dan meminta mereka bertanya kepada peneliti jika ada hal yang kurang dipahami. Setelah itu

Welan Mauli Angguna, Fakultas Psikologi Universitas Putra Indonesia 'YPTK', Padang Indonesia, Email: welanmauli@gmail.com 


\section{PENGARUH TRAIT KEPRIBADIAN TERHADAP AKTIVITAS FISIK}

responden disilakan untuk mengerjakan

kuesioner.

\section{Alat Ukur}

1. International

Physical

Activity

Questionnaire (IPAQ) versi panjang, adalah alat ukur yang digunakan untuk menilai aktivitas fisik/olahraga individu. IPAQ mengukur aktivitas fisik dalam berbagai domain, yakni domain pekerjaan, berkendara, mengerjakan pekerjaan rumah, dan domain rekreasi-olahraga. Individu akan melaporkan frekuensi dan durasi aktivitas berjalan, aktivitas moderat dan berat yang dilakukan dalam durasi minimal 10 menit per sesi. Laporan durasi dalam menit per minggu di setiap kategori ditimbang dengan metabolic equivalent Task ([MET]; perkalian sisa energy yang dihabiskan) hasil estimasi aktivitas terpisah ditampilkan dalam METmenit/minggu dan dihitung dengan mengalikan MET dari menit/minggu.

Rumus Aktivitas Fisik: *Penjelasan mengenai perhitungan aktivitas fisik bisa dilihat di lampiran.

2. The Big Five Personality Inventory (BFI) adalah alat ukur yang digunakan untuk menilai trait kepribadian individu. Inventori ini mengukur trait kepribadian individu berdasarkan lima dimensi: ekstraversi, conscientiousness, agreeableness, neuroticism, dan openness. Inventori ini adalah hasil adaptasi The Big Five inventory versi 44 aitem (John \& Sirastava, 1999) yang diadaptasi oleh Ramdhani (2012) menjadi BFI yang terdiri atas 28 aitem dengan penilaian 5 skala (1= sangat tidak setuju) hingga (5= sangat setuju). Inventori ini memiliki nilai reliabilitas $0,70-0,79$ dan validitas 0,4 - 0,8 pada masing-masing dimensi.

3. Data Demografis. Data demografis terdiri atas usia, jenis kelamin, pendidikan, status pekerjaan (bekerja/mahasiswa), tinggi-berat badan, dan apakah rutin berolahraga atau tidak.

Analisis data dilakukan menggunakan bantuan aplikasi SPSS 21 for Windows. Untuk melihat pengaruh trait kepribadian terhadap aktivitas fisik dilakukan melalui multiple regression, kemudian untuk melihat perbedaan setiap variabel berdasarkan jenis kelamin dan rutinitas berolahraga diuji menggunakan independent sample T-test.

Welan Mauli Angguna, Fakultas Psikologi Universitas Putra Indonesia 'YPTK', Padang Indonesia, Email: welanmauli@gmail.com 


\section{HASIL}

Tabel 1.

Gambaran Responden

\begin{tabular}{ccccc}
\hline Kategori & $\mathbf{N}$ & Keterangan & Frekuensi & Persentase (\%) \\
\hline \multirow{2}{*}{ Jenis Kelamin } & \multirow{2}{*}{33} & Laki-laki & 12 & 36,4 \\
& & Perempuan & 21 & 63,6 \\
\hline \multirow{3}{*}{ Usia } & 18 & 3 & 9,1 \\
& 20 & 3 & 9,1 \\
& \multirow{2}{*}{33} & 21 & 8 & 24,2 \\
& & 22 & 4 & 12,1 \\
& 23 & 6 & 18,2 \\
& & 24 & 6 & 18,2 \\
\multirow{2}{*}{ Pendidikan } & 25 & 2 & 6,1 \\
& \multirow{2}{*}{33} & 26 & 1 & 3,0 \\
\hline \multirow{2}{*}{ Pekerjaan } & S1 & 14 & 42,4 \\
& \multirow{2}{*}{33} & SMA & 19 & 57,6 \\
\hline Status BMI & Bekerja & 8 & 24,2 \\
& & Mahasiswa & 25 & 75,8 \\
\hline & & Kekurangan berat & 8 & 24,2 \\
& & Berat badan sehat & 18 & 54,5 \\
& & Kelebihan berat & 7 & 21,2 \\
\hline
\end{tabular}

Penelitian ini diujikan pada kelompok dewasa muda yang berusia 19 hingga 26 tahun.

Berdasarkan tabel 1 dapat diketahui bahwa rata-rata responden berjenis kelamin perempuan (63,6\%), berusia $23-24$ tahun $(36,4 \%)$, memiliki status mahasiswal belum bekerja $(75,8 \%)$, dan memiliki pendidikan terakhir setingkat SMA $(57,6 \%)$. Jika dilihat berdasarkan status indeks massa tubuh, rata-rata responden pada kelompok penelitian ini memiliki berat badan sehat $(54,5 \%)$.

\section{Tabel 2.}

\section{Gambaran Total Aktivitas Fisik}

\begin{tabular}{ccccc}
\hline \multirow{2}{*}{ Variabel } & \multicolumn{4}{c}{ Skor Aktivitas Fisik dalam MET } \\
\cline { 2 - 5 } & Minimum & Maksimum & Rata-rata & SD \\
\hline Aktivitas Fisik & 222 & 19.476 & $4.927,80$ & 4746,91 \\
\hline
\end{tabular}

Ket: Total Aktivitas Fisik adalah penjumlahan skor (MET) berjalan + aktivitas sedang + aktivitas berat pada setiap individu.

Berdasarkan gambaran aktivitas fisik pada tabel 2 dapat diketahui bahwa nilai rata-rata aktivitas fisik berdasarkan MET (Metabolic Equivalent Task) pada kelompok responden studi ini adalah 4.927 MET, kelompok responden penelitian ini memiliki skor aktivitas fisik paling rendah sebesar $222 \mathrm{MET}$, sedangkan nilai tertinggi adalah sebesar 19.476 MET.

Welan Mauli Angguna, Fakultas Psikologi Universitas Putra Indonesia 'YPTK', Padang Indonesia, Email: welanmauli@gmail.com 
Tabel 3.

Gambaran Aktivitas Fisik Berdasarkan Setiap Domain

\begin{tabular}{cccccc}
\hline \multirow{2}{*}{ Domain } & Aktivitas & \multicolumn{4}{c}{ Skor Aktivitas dalam MET } \\
\cline { 3 - 6 } & & Minimum & Maksimum & Rata-rata & SD \\
\hline \multirow{3}{*}{ Pekerjaan } & Berjalan & 0 & 5544 & 780,50 & 1391,26 \\
& Sedang & 0 & 2880 & 396,36 & 606,33 \\
\multirow{2}{*}{ Transportasi } & Berat & 0 & 7680 & 901.82 & 1604,40 \\
& Berjalan & 0 & 5544 & 944,00 & 1324,05 \\
Pekerjaan Rumah & Bersepeda & 0 & 1080 & 48,18 & 195,28 \\
& Berat di luar rumah & 0 & 2970 & 296,67 & 675,98 \\
Rekreasi, Olahraga & Sedang di luar rumah & 0 & 1680 & 280,00 & 435,55 \\
& Sedang di dalam rumah & 0 & 3780 & 491,36 & 781,22 \\
& Berjalan & 0 & 1386 & 258,00 & 434,93 \\
& Sedang & 0 & 1440 & 112,73 & 317,40 \\
& Berat & 0 & 3840 & 418,18 & 925,69 \\
\hline \multirow{2}{*}{ Total Aktivitas Berjalan } & 0 & 12.276 & 1982,50 & 2955,55 \\
Total Aktivitas Sedang & 0 & 4.140 & 1328,64 & 1166,10 \\
Total Aktivitas Berat & 0 & 10.350 & 1616,67 & 2422,69 \\
\hline
\end{tabular}

Apabila ditinjau pada setiap domain alat ukur: domain pekerjaan, domain transportasi, domain

pekerjaan rumah, dan domain rekreasi-olahraga, dapat diketahui bahwa nilai minimum aktivitas pada setiap domain adalah 0 , artinya di setiap aktivitas pada setiap domain selalu ada responden yang tidak melakukan aktivitas tersebut sama sekali dalam 7 hari terakhir. Aktivitas berjalan memiliki nilai rata-rata yang cukup tinggi daripada aktivitas lainnya. Aktivitas bersepeda (kategori aktivitas sedang) memiliki nilai rata-rata yang paling kecil dibandingkan aktivitas lainnya pada kelompok responden ini. Jika setiap semua aktivitas pada setiap domain dijumlahkan dapat diketahui bahwa aktivitas berjalan memiliki nilai rata-rata yang paling tinggi, sedangkan aktivitas sedang memiliki nilai rata-rata yang jauh lebih rendah daripada aktivitas berjalan dan berat.

Tabel 4.

Gambaran Trait Kepribadian

\begin{tabular}{cccccc}
\hline Variabel & Minimum & Maximum & Rata-rata & SD & Jumlah aitem \\
\hline Extraversion & 11 & 24 & 17.85 & 2.90 & 5 \\
Agreeableness & 21 & 30 & 25.03 & 2.30 & 7 \\
Conscientiousness & 13 & 25 & 21.06 & 2.95 & 6 \\
Openness & 14 & 27 & 21.52 & 3.33 & 6 \\
Neuroticism & 8 & 17 & 12.36 & 2.42 & 4 \\
\hline
\end{tabular}

Gambaran trait kepribadian pada kelompok responden ini dapat dilihat pada tabel 4, nilai minimum dan maksimum setiap trait adalah berdasarkan nilai yang ada pada kelompok responden ini. Trait openness memiliki nilai rata-rata paling tinggi sebesar $21,52(S D=3,33)$, sedangkan trait neuroticism memiliki skor rata-rata paling rendah yakni $12,36(S D=2,42)$.

Welan Mauli Angguna, Fakultas Psikologi Universitas Putra Indonesia 'YPTK', Padang Indonesia, Email: welanmauli@gmail.com 


\section{Analisis Regresi Trait Kepribadian terhadap Aktivitas Fisik}

Tabel 5.

Model Summary

\begin{tabular}{ccccc}
\hline Model & $\mathbf{R}$ & $\mathbf{R}^{\mathbf{2}}$ & Adjusted $\mathbf{R}^{2}$ & $\begin{array}{c}\text { Estimasi Standar } \\
\text { Eror }\end{array}$ \\
\hline 1 & 0,65 & 0,42 & 0,32 & 3921,14 \\
\hline Melalui tabel 5 dapat diketahui & bahwa trait kepribadian memengaruhi & aktivitas fisik secara \\
signifikan dengan kontribusi adjusted & $R^{2}$ sebesar 0,32 . Artinya trait kepribadian mampu menjelaskan \\
aktivitas fisik sebesar 32\%, dan sisanya dijelaskan oleh variabel lainnya.
\end{tabular}

Tabel 6.

Analisis Varian (Anova)

\begin{tabular}{ccccccc}
\hline \multirow{2}{*}{ Model } & & $\begin{array}{c}\text { Sum of } \\
\text { Squares }\end{array}$ & Df & $\begin{array}{c}\text { Mean } \\
\text { Square }\end{array}$ & F & sig. \\
\hline \multirow{2}{*}{1} & Regression & 305926826,18 & 5 & 61185365,24 & & \\
& Residual & 415134752,29 & 27 & 15375361,20 & 3,98 & 0,01 \\
& Total & 721061578.47 & 32 & & & \\
\hline
\end{tabular}

Pada table 6 diketahui bahwa nilai $F=3,98$ dengan signifikansi $p<0,05$ sehingga Ha diterima dan

Ho ditolak, artinya variabel bebas yakni trait memiliki kontribusi memengaruhi aktivitas fisik.

Tabel 7.

Koefisien

\begin{tabular}{cccccccc}
\hline \multirow{2}{*}{ Model } & \multicolumn{2}{c}{ Unstandardized Coefficient } & & & \multicolumn{2}{c}{ Collinearity } \\
\cline { 3 - 4 } & B & E Standard & T & Sig & Tolerance & VIF \\
\hline 1 & (Constant) & 10782,53 & $-27417,80$ & & & & \\
extraversion & $-816,83$ & 361,19 & $-2.26^{*}$ & 0,03 & 0,439 & 2,28 \\
& agreeableness & 942,13 & 326,53 & $2.89^{*}$ & 0,01 & 0,853 & 1,17 \\
& conscientiousness & 489,19 & 296,79 & 1.65 & 0,11 & 0,628 & 1,59 \\
& openness & 721,19 & 277,75 & $2.60^{*}$ & 0,02 & 0,563 & 1,78 \\
& neuroticism & $-200,27$ & 317,38 & -.63 & 0,53 & 0,813 & 1,23 \\
\hline & Berdasarkan Tabel 7 dapat diketahui bahwa tidak semua trait kepribadian memengaruhi aktivitas
\end{tabular}

fisik. Hanya trait kepribadian ekstraversion, agreeableness, dan openness yang memengaruhi aktivitas fisik secara signifikan. Trait extraversion memengaruhi aktivitas fisik secara negatif dengan nilai T $-2,26$ $(p<0,05)$, artinya semakin rendah skor extraversi seseorang maka semakin tinggi aktivitas fisiknya. Arah hubungan ini sama dengan trait neuroticism, namun neuroticism tidak memengaruhi aktivitas fisik secara signifikan $(p>0,05)$. Kemudian, trait agreeableness dan openness memengaruhi aktivitas fisik secara positif, semakin tinggi nilai agreeableness dan keterbukaan (openness) maka akan semakin tinggi juga aktivitas fisik individu.

Welan Mauli Angguna, Fakultas Psikologi Universitas Putra Indonesia 'YPTK', Padang Indonesia, Email: welanmauli@gmail.com 
PENGARUH TRAIT KEPRIBADIAN TERHADAP AKTIVITAS FISIK

Uji Perbedaan Aktivitas Fisik Kelompok berdasarkan Jenis Kelamin dan Rutinitas Olahraga

Tabel 8.

Statistik Kelompok

\begin{tabular}{ccccc}
\hline Variabel & Kelompok & N & Rata-rata & SD \\
\hline Aktivitas Fisik & Laki-laki & 12 & 8311,63 & 5915,09 \\
& Perempuan & 21 & 2994,19 & 2452,26 \\
\hline
\end{tabular}

Berdasarkan tabel 8 dapat diketahui bahwa responden laki-laki lebih sedikit daripada responden perempuan pada kelompok studi ini. Laki-laki memiliki skor rata-rata aktivitas fisik yang lebih tinggi daripada perempuan.

Tabel 9.

Independent Sample T-Test

\begin{tabular}{llllllll}
\hline \multirow{2}{*}{ Variabel } & \multicolumn{2}{l}{$\begin{array}{l}\text { Lavene's test for } \\
\text { equality of variance }\end{array}$} & \multicolumn{2}{l}{ T-test for equality of variance } & \multirow{2}{*}{$\begin{array}{c}\text { Perbedaan } \\
\text { rata-rata }\end{array}$} \\
\cline { 2 - 7 } & $\mathbf{F}$ & Sig. & T & df. & Sig. & \\
\hline Aktivitas Fisik & 14,09 & 0,00 & 2,97 & 13,20 & 0,01 & 5317,44 \\
\hline
\end{tabular}

Berdasarkan tabel 9 dapat diketahui bahwa jenis kelamin secara signifikan mampu membedakan aktivitas fisik dengan nilai F 14,09 ( $p<0,05)$ dan memiliki perbedaan rata-rata aktivitas fisik antara laki-laki dan perempuan sebesar 5.317. Jenis kelamin juga mampu membedakan trait kepribadian ekstraversi dengan nilai $6,18(p<0,05)$ dan perbedaan rata-rata 1,29 , begitu juga mampu membedakan trait kepribadian conscientiousness secara signifikan sebesar 4,66 $(p<0,05)$ dengan perbedaan rata-rata 2,13.

Tabel 10.

Independent Sample T-Test

\begin{tabular}{ccccccc}
\hline \multirow{2}{*}{ Variabel } & \multicolumn{3}{c}{$\begin{array}{l}\text { Lavene's test for } \\
\text { equality of variance }\end{array}$} & \multicolumn{2}{c}{ T-test for equality of variance } & \multirow{2}{*}{$\begin{array}{c}\text { Perbedaan } \\
\text { rata-rata }\end{array}$} \\
\cline { 2 - 6 } & F & Sig. & T & df. & $\begin{array}{c}\text { sig. } \\
\text { (2- tailed) }\end{array}$ & \\
\hline Aktivitas Fisik & 13,02 & 0,00 & 2,37 & 9,51 & 0,04 & 5203,19 \\
\hline
\end{tabular}

Berdasarkan tabel 10 diketahui bahwa rutin atau tidaknya seseorang berolahraga secara signifikan mampu membedakan aktivitas fisik dengan nilai 13,02 $(p<0,05)$ dengan perbedaan rata-rata skor aktivitas fisik sebesar 5.203. Kerutinan dalam berolahraga juga mampu mampu membedakan nilai ekstraversi secara signifikan sebesa 5,59 $(p<0,05)$ dengan perbedaan rata-rata skor ekstraversi 1,28.

Welan Mauli Angguna, Fakultas Psikologi Universitas Putra Indonesia 'YPTK', Padang Indonesia, Email: welanmauli@gmail.com 


\section{PENGARUH TRAIT KEPRIBADIAN TERHADAP AKTIVITAS FISIK}

\section{DISKUSI}

Tujuan penelitian ini adalah untuk mengetahui apakah trait kepribadian memengaruhi aktivitas fisik secara signifikan pada kelompok dewasa muda di Indonesia. Dapat diketahui bahwa trait kepribadian mampu memberikan penjelasan mengenai aktivitas fisik sebesar 32\%, dan sisanya dijelaskan oleh variabel lain. Akan tetapi tidak semua trait kepribadian secara signifikan memengaruhi aktivitas fisik, hanya trait kepribadian ekstraversi, agreeableness, dan openness yang secara signifikan memengaruhi aktivitas fisik, yaitu semakin tinggi trait agreeableness dan openness serta semakin rendah trait ekstraversi maka semakin tinggi aktivitas fisik. Berbeda dengan hasil meta-analisis Rhodes \& Smith (2006) yang menyimpulkan dari berbagai penelitian trait kepribadian dan aktivitas fisik bahwa semakin tinggi skor ekstraversi dan conscientiousness serta rendahnya neuroticism maka semakin tinggi aktivitas fisik. Sesungguhnya pola hubungan antara trait kepribadian terhadap aktivitas fisik cenderung berbeda-beda variasinya tergantung karakteristik sampel yang digunakan (Wilson \& Dishman, 2015), walaupun sampel yang digunakan sama-sama pada kelompok dewasa muda, namun terdapat karakteristik sampel tertentu yang berbeda sehingga memengaruhi perbedaan hasil, seperti adanya perbedaan budaya yang dibawa oleh responden.

Dari kelima trait kepribadian, diketahui trait ekstraversi dan neuroticism secara negatif berhubungan dengan aktivitas fisik, namun hanya ekstraversi yang memengaruhi secara signifikan. Hal serupa ditemukan oleh Lochbaum, Rhodes, Stevenson, Surles, Stevens, \& Wang (2010) bahwa neuroticism tidak cukup signifikan berhubugan dengan aktivitas fisik. Trait kepribadian agreeableness diketahui signifikan mengaruhi aktivitas fisik, diketahui bahwa individu dengan skor agreeablenesss tinggi cenderung percaya, murah hati, patuh, menerima (Costa \& McCrae, 2013), bisa dikatakan mereka adalah orang yang bersahaja yang mudah diajak melakukan berbagai hal, suka menolong, dan jika mendapatkan promosi kesehatan mereka mungkin lebih mau untuk patuh mengikutinya. Selain itu semakin tinggi keterbukaan seseorang semakin tinggi pula aktivitas fisiknya, orang yang terbuka cenderung mampu menerima keberagaman dan informasi baru dan keterbukaan sering dikaitkan dengan inteligensi (Feist \& Feist, 2008), jadi orang yang terbuka cenderung mau mencari informasi baru dan dengan inteligensi yang baik mereka mungkin bisa memahami betapa pentingnya aktif dalam beraktivitas, sehingga keterbukaan secara positif memprediksi aktivitas fisik.

Namun, hal paling menarik yang ditemukan pada studi ini adalah trait kepribadian ekstraversi secara negatif memengaruhi aktivitas fisik secara signifikan, berbeda dengan temuan sebelumnya yang menemukan bahwa rendahnya neuroticism dan tinggi nya ekstraversi berkaitan dengan semakin sering

Welan Mauli Angguna, Fakultas Psikologi Universitas Putra Indonesia 'YPTK', Padang Indonesia, Email:welanmauli@gmail.com 


\section{PENGARUH TRAIT KEPRIBADIAN TERHADAP AKTIVITAS FISIK}

dan semakin intens individu melakukan aktivitas

fisik (Butkovic, Hlupic, \& Bratko 2017). Feist dan Feist (2008) menggambarkan individu dengan ekstraversi tinggi cenderung afektif, periang, ramah, senang berkelompok, dan menyenangkan. Jika dilihat dari karakteristik ini kita cenderung berpikir bahwa semakin tinggi ekstraversi semakin tinggi pula aktivitas fisik karena mereka seharusnya lebih aktif, namun pada studi ini tidak ditemukan hal demikian. Namun, individu dengan ekstraversi tinggi secara biologis memiliki cortisol arousal yang lebih rendah, dan menunjukkan peforma yang lebih buruk ketika melakukan tugas yang monoton karena rendahnya stimulasi, sebaliknya individu yang introvert lebih sensitif terhadap stimulasi (Feist \& Feist, 2008). Aktivitas fisik pada studi ini diukur melalui selfreport dengan menjawab pertanyaan kuesioner, hal ini mengharuskan responden untuk mengingat-ingat kembali seberapa lama mereka melakukan aktivitas fisik yang ditanyakan dalam tujuh hari terakir, hal ini mungkin menjadi beban bagi orang yang ekstrovert sehingga mungkin saja terdapat eror dalam pelaporan aktivitas fisik. Kemungkinan lain adalah karena aktivitas fisik yang diukur di sini adalah aktivitas fisik yang rutin dilakukan sehari-hari, sedangkan orang yang ekstrovert lebih menyukai aktivitas yang memiliki stimulasi tinggi, sehingga mereka tidak begitu aktif dalam melakukan aktivitas fisik rutin di setiap hari.

Berdasarkan uji beda diketahui bahwa jumlah responden laki-laki lebih sedikit daripada perempuan, laki-laki pada kelompok ini memiliki skor aktivitas fisik yang lebih tinggi daripada perempuan dan perbedaan skor aktivitas fisik antara laki-laki dan perempuan adalah signifikan. Sejalan dengan temuan sebelumnya bahwa laki-laki cenderung memiliki aktivitas fisik lebih tinggi daripada perempuan (Rhodes \& Smith, 2006; Lochbaum, Rhodes, Stevenson, Surles, Stevens, \& Wang 2010; Asci, Lindwall, Altintas, \& Gursel 2015). Hal ini mungkin disebabkan oleh faktor dukungan sosial yang mana laki-laki lebih diterima untuk melakukan aktivitas fisik sejalan dengan nilai ideal tentang masukilinitas (terkait kekuatan fisik), terkhusus untuk negara non-barat perspektif sosial dan ekspektasi budaya terkait aktivitas fisik membedakan aktivitas fisik antara laki-laki dan perempuan (Coen, Rosenberg, \& Davidson, 2018; Asci, Lindwall, Altintas, \& Gursel 2015). Selain itu juga terdapat perbedaan skor aktivitas fisik antara kelompok yang rutin berolahraga dan yang tidak, dan kelompok yang rutin berolahraga semuanya adalah laki-laki, perbedaan proporsi jumlah laki-laki dan perempuan, serta kelompok yang rutin berolahraga dan yang tidak mungkin memengaruhi hasil terkait pengaruh kepribadian terhadap aktivitas fisik.

Diketahui bahwa responden penelitian ini adalah kelompok usia dewasa muda dengan pendidikan terakhir S1 dan SMA, sebagian besar responden adalah mahasiswa atau belum bekerja $(75,8 \%)$, dan hanya 9 dari 33 responden yang rutin berolahraga. Schuval, Li, Gabriel, \&

Welan Mauli Angguna, Fakultas Psikologi Universitas Putra Indonesia 'YPTK', Padang Indonesia, Email: welanmauli@gmail.com 


\section{PENGARUH TRAIT KEPRIBADIAN TERHADAP AKTIVITAS FISIK}

Tchernis (2017) menunjukkan bahwa semakin tinggi pendapatan individu semakin tinggi intensitas aktivitas fisik, dimana kelompok ini secara sadar mengalokasikan waktu untuk melakukan aktivitas fisik. Berbeda dengan orang yang memiliki pendapatan lebih rendah cenderung melakukan aktivitas fisik dengan frekuensi yang rutin namun intensitas yang ringan, dan mereka tidak secara sengaja mengalokasikan waktu untuk hal ini (Shuval, Li, Gabriel, \& Tchernis, 2017). Diketahui bahwa kelompok responden penelitian ini sebagian besar adalah mahasiswa, bisa dikatakan mereka belum memiliki pendapatan sendiri, hal ini menjadi masuk akal ketika diketahui bahwa nilai rata-rata aktivitas berjalan adalah yang paling tinggi daripada aktivitas sedang dan aktivitas berat.

\section{SIMPULAN DAN SARAN}

Kepribadian khususnya trait kepribadian ekstraversi, agreeableness, dan ekstraversi memengaruhi aktivitas fisik secara signifikan pada kelompok dewasa muda. Terdapat perbedaan skor aktivitas fisik, ekstraversi, dan conscientiousness antara lakilaki dan perempuan, juga terdapat perbedaan skor aktivitas fisik dan ekstraversi antara kelompok yang rutin berolahraga dan yang tidak.

Melalui berbagai paparan diskusi hasil penelitian ini, penelitian selanjutnya disarankan untuk melakukan kontrol dalam pengambilan sampel, yakni ukuran sampel yang lebih besar dengan proporsi yang lebih seimbang antara laki-laki dan perempuan, begitu juga antara kelompok yang rutin berolahraga dan yang tidak. Selain itu, perlu dilakukan analisis pengaruh kepribadian terhadap aktivitas fisik yang dibedakan antara laki-laki dan perempuan, lalu antara kelompok yang rutin berolahraga dengan yang tidak, penting juga memperhatikan faktor eksternal lain yang mungkin memengaruhi seperti motivasi, dukungan sosial, pendapatan, dan fasilitas yang mendukung untuk individu dalam melakukan aktivitas fisik. Terkait cara pengukuran aktivitas fisik, mungkin bisa dikembangkan dengan cara yang lebih baik seperti melalui wawancara untuk mendapatkan gambaran yang lebih akurat.

\section{DAFTAR PUSTAKA}

Apriana, W., Julia, M., \& Huriyati, E. (2015). Hubungan Aktivitas Fisik dengan Kualitas Tidur Remaja di Yogyakarta. Skripsi, tidak diterbitkan, Universitas Gadjah Mada, Yogyakarta.

Aşçı, F. H., Lindwall, M., Alııntaş, A., \& Gürsel, N. E. (2015). Gender differences in the relation of personality traits and selfpresentation with physical activity. Science \& Sports, 30(1), e23-e30.

Butković, A., Hlupić, T. V., \& Bratko, D. (2017). Physical activity and personality: a behaviour genetic analysis. Psychology of sport and exercise, 30, 128-134.

Coen, S. E., Rosenberg, M. W., \& Davidson, J. (2018). "It's gym, like gym not Jim": Exploring the role of place in the

Welan Mauli Angguna, Fakultas Psikologi Universitas Putra Indonesia 'YPTK', Padang Indonesia, Email:welanmauli@gmail.com 


\section{PENGARUH TRAIT KEPRIBADIAN TERHADAP AKTIVITAS FISIK}

gendering of physical activity. Social Science \& Medicine, 196, 29-36.

Conroy, D. E., Motl, R. W., \& Hall, E. G. (2000). Progress toward construct validation of the self-presentation in exercise questionnaire (SPEQ). Journal of Sport and Exercise Psychology, 22, 21-38.

Costa Jr, P. T., \& McCrae, R. R. (2013). Personality in adulthood: A five-factor theory perspective. Guilford Press.

Dishman, R. K., Sallis, J. F., \& Orenstein, D. R. (1985). The determinants of physical activity and exercise. Public health reports, 100(2), 158.

Feist, J., \& Feist, G. J. (2008). Theories of personality. McGraw-Hill.

Israel, S., Moffitt, T. E., Belsky, D. W., Hancox, R. J., Poulton, R., Roberts, B., Thomson, W.M., \& Caspi, A. (2014). Translating personality psychology to help personalize preventive medicine for young adult patients. Journal of personality and social psychology, 106(3), 484.

Kern, M. L., Reynolds, C. A., \& Friedman, H. S. (2010). Predictors of physical activity patterns across adulthood: a growth curve analysis. Personality and Social Psychology Bulletin, 36(8), 1058-1072.
Lochbaum, M. R., Rhodes, R. E., Stevenson, S. J., Surles, J., Stevens, T., \& Wang, C. K. J. (2010). Does gender moderate the exercising personality? An examination of continuous and stage-based exercise. Psychology, health \& medicine, 15(1), 5060.

Macovei, S., Tufan, A. A., \& Vulpe, B. I. (2014). Theoretical approaches to building a healthy lifestyle through the practice of physical activities. Procedia-Social and Behavioral Sciences, 117, 86-91.

Rhodes, R. E., \& Smith, N. E. I. (2006). Personality correlates of physical activity: a review and meta-analysis. British journal of sports medicine, 40(12), 958965.

Rhodes, R. E., \& Nigg, C. R. (2011). Advancing physical activity theory: A review and future directions. Exercise and sport sciences reviews, 39(3), 113-119.

Shuval, K., Li, Q., Gabriel, K. P., \& Tchernis, R. (2017). Income, physical activity, sedentary behavior, and the 'weekend warrior'among US adults. Preventive medicine, 103, 91-97.

Stephan, Y., Sutin, A. R., \& Terracciano, A. (2014). Physical activity and personality development across adulthood and old age: Evidence from two longitudinal studies. Journal of Research in Personality, 49, 1-7.

Wilson, K. E., \& Dishman, R. K. (2015). Personality and physical activity: A systematic review and meta-analysis. Personality and Individual Differences, 72, 230-242.

Welan Mauli Angguna, Fakultas Psikologi Universitas Putra Indonesia 'YPTK', Padang Indonesia, Email: welanmauli@gmail.com 
PENGARUH TRAIT KEPRIBADIAN TERHADAP AKTIVITAS FISIK

\section{LAMPIRAN}

\section{Rumus Perhitungan Aktivitas Fisik}

a. Domain Kerja

- Berjalan MET menit/minggu= 3,3 $x$ berjalan (menit ) $x$ berjalan (hari)

- Aktivitas sedang MET menit/minggu= 4,0 $x$ aktivitas sedang (menit) $x$ aktivitas sedang (hari)

- Aktivitas Berat MET menit/minggu $=8,0 \times$ aktivitas berat (menit) $\mathrm{x}$ aktivitas berat (hari) Jumlah domain kerja MET menit/minggu= berjalan + aktivitas sedang + aktivitas berat MET menit/minggu

b. Domain Transportasi

- Berjalan MET menit/minggu $=3,3 \times$ berjalan (menit) $x$ berjalan (hari)

- Bersepeda MET menit/minggu $=6,0 \mathrm{x}$ bersepeda (menit) $\mathrm{x}$ bersepeda (hari) Jumlah domain transportasi MET menit/minggu= berjalan = bersepeda MET menit/minggu

c. Domain Pekerjaan Rumah

- Aktivitas Berat di luar rumah MET menit/minggu= 5,5 $\times$ aktivitas berat (mnit) $\mathrm{x}$ berat (hari)

- Aktivitas Sedang di luar rumah MET menit/minggu= 4,0 $x$ aktivitas berat (mnit) $\times$ berat (hari)

- Aktivitas Sedang di dalam rumah MET menit/minggu= 3,0 $\mathrm{x}$ aktivitas berat (mnit) $\mathrm{x}$ berat (hari)

Jumlah domain pekerjaan rumah $=$ aktivitas berat $=$ aktivitas sedang + aktivitas sedang MET menit/minggu

d. Domain Rekreasi-olahraga

- Berjalan MET menit/minggu= 3,3 $\times$ berjalan (menit) $\times$ berjalan (hari)

- Aktivitas sedang MET menit/minggu= 4,0 $x$ aktivitas sedang (menit) $x$ aktivitas sedang (hari)

- Aktivitas berat MET menit/minggu= $8,0 \times$ aktivitas berat (menit) $x$ aktivitas berat (hari) Jumlah domain rekreasi-olahraga menit/minggu= berjalan + aktivitas sedang + aktivitas berat Jumlah Skor Aktivitas Berjalan, aktivitas fisik sedang, dan aktivitas fisik berat

- Jumlah berjalan MET menit/minggu= berjalan MET menit/minggu (domain bekerja + transportasi + rekreasi-olahraga)

- Jumlah aktivitas sedang MET menit/minggu= aktivitas sedang MET menit/minggu (domain kerja + pekerjaan di luar rumah + pekerjaan di dalam rumah + rekreasi-olahraga)

- Jumlah aktivitas berat MET menit/minggu= kuat MET menit/minggu (bekerja + rekreasiolahraga).

TOTAL Aktivitas Fisik = Jumlah Berjalan MET menit/minggu + Jumlah Aktivitas Sedang MET menit/minggu + Jumlah Aktivitas Berat MET menit/minggu

Welan Mauli Angguna, Fakultas Psikologi Universitas Putra Indonesia 'YPTK', Padang Indonesia, Email: welanmauli@gmail.com 